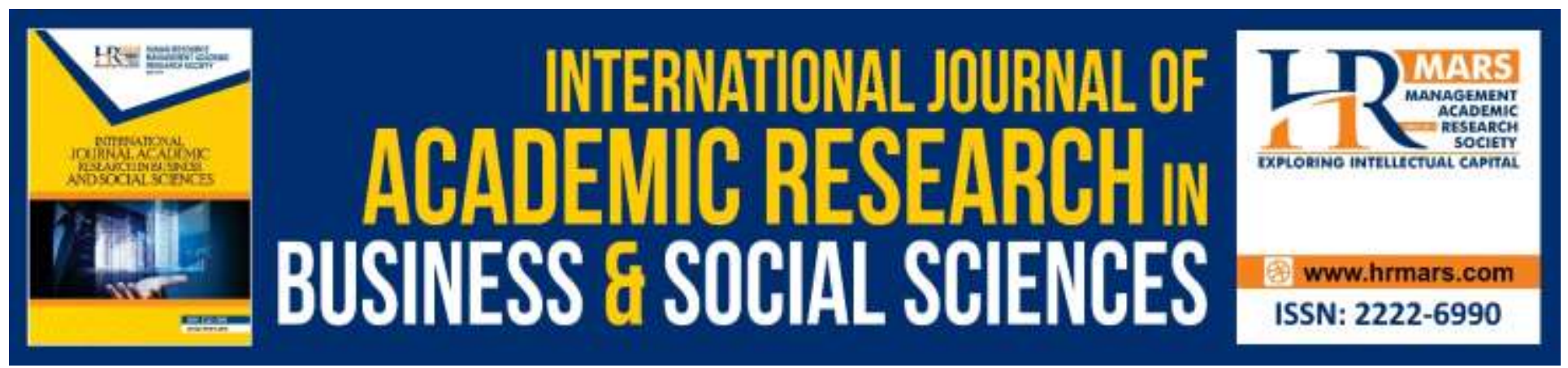

\title{
Online Case-Based Problem-Solving Module for ESL Teacher Education
}

\section{Nazeera Ahmed Bazari}

To Link this Article: http://dx.doi.org/10.6007/IJARBSS/v9-i13/6867

DOI:10.6007/IJARBSS/v9-i13/6867

Received: 23 June 2019, Revised: 19 July 2019, Accepted: 05 August 2019

Published Online: 28 August 2019

In-Text Citation: (Bazari, 2019)

To Cite this Article: Bazari, N. A. (2019). Online Case-Based Problem-Solving Module for ESL Teacher Education. International Journal of Academic Research in Business and Social Sciences, 9(13), 400-415.

Copyright: (C) 2019 The Author(s)

Published by Human Resource Management Academic Research Society (www.hrmars.com)

This article is published under the Creative Commons Attribution (CC BY 4.0) license. Anyone may reproduce, distribute, translate and create derivative works of this article (for both commercial and non-commercial purposes), subject to full attribution to the original publication and authors. The full terms of this license may be seen

at: http://creativecommons.org/licences/by/4.0/legalcode

Special Issue: Revolutionizing Education: Challenges, Innovation, Collaboration, 2019, Pg. 400 - 415 http://hrmars.com/index.php/pages/detail/IJARBSS

Full Terms \& Conditions of access and use can be found at http://hrmars.com/index.php/pages/detail/publication-ethics 


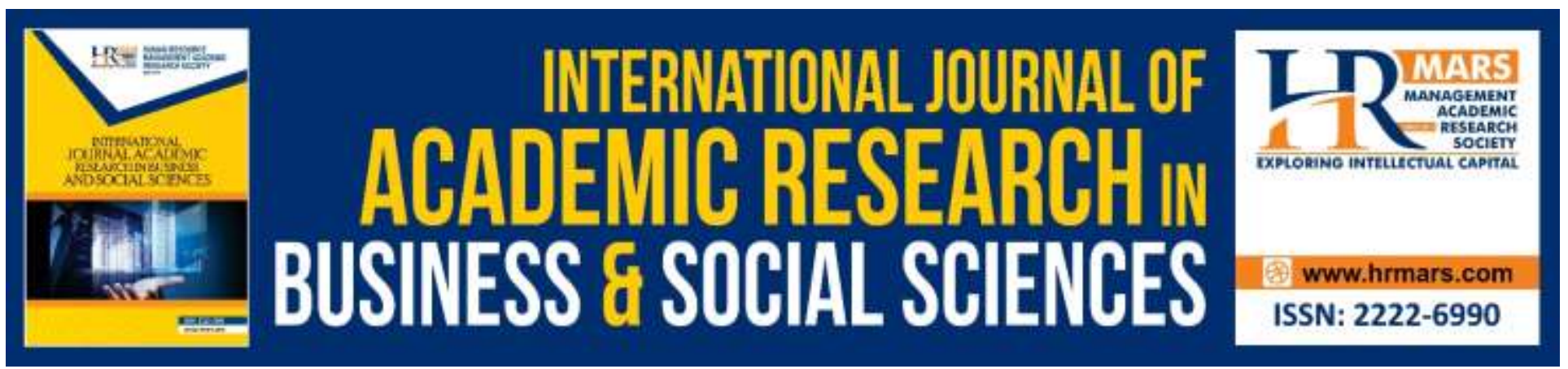

\title{
Online Case-Based Problem-Solving Module for ESL Teacher Education
}

\author{
Nazeera Ahmed Bazari \\ Universiti Teknologi MARA, Malaysia
}

\begin{abstract}
In Malaysia, efforts to increase the quality of students' learning and achievement, and teachers' quality of delivery and instruction have been ongoing as documented in the National Education Blueprints 2015-2025. The complex nature of the teaching profession requires problem-solving skills to be instilled in teachers to ensure they are able to face the demands of the teaching profession and increase the quality of their instruction. However, research has shown that higher education has not adequately prepared pre-service teachers with problem-solving skills, pedagogical content knowledge, ability to bridge theory and practice, and to be adequately prepared to teach. Hence, this study is carried out to develop and implement an Online Case-Based Problem-Solving (OCBPS) Module to enhance problem-solving skills and other vital skills that can increase the competency of Teaching English as a Second Language (TESL) pre-service teachers. Pre-service teachers observe an authentic ESL writing lesson and engage in problem-solution analysis relating to pedagogy and content of ESL writing. A Single-Group Pre-test-Post-test Design is adopted in which scores of prereflection essays written by the pre-service teachers before the implementation of the module, and the scores of post reflective essays written at the end of the module implementation are compared. The findings for usability indicate that the OCBPS module has the potential of developing vital skills in ESL pre-service teachers like problem-solving skills, pedagogical content knowledge, and the ability to bridge theory and practice.
\end{abstract}

Keywords: Case-Based Learning, Pedagogical Content Knowledge, Problem-Solving, Bridge Theory and Practice, Teacher Education, Pre-Service Teachers

\section{Introduction}

Producing high quality teachers through professional development programs, life-long learning initiatives, and teacher education courses are part of the initiatives highlighted in the Malaysian National Education Blueprint 2013-2025 and 2015-2025 (Ministry of Education (MOE), 2014; MOE 2015). The most important element of quality education is the quality of the teacher (Moore, 2014). Teacher education programs are expected to carry out the government's aspirations of producing high quality teachers who are competent in their job. There have been constant 
INTERNATIONAL JOURNAL OF ACADEMIC RESEARCH IN BUSINESS AND SOCIAL SCIENCES

Vol. 9, No. 13, Special Issue: Revolutionizing Education: Challenges, Innovation, Collaboration., 2019, E-ISSN: 2222-6990 @ 2019 HRMARS

measures to upgrade teachers' competencies and efforts have been taken towards achieving this aspiration (MOE, 2014; MOE 2015).

Teachers are the backbone of any education system. Their training and preparation need to focus on producing educators with contemporary skills that are useful in this era. They need to reach their students through interesting content, engaging activities and varied pedagogies for effective delivery of lessons (MOE, 2014; MOE 2015). They are responsible for their students' progress and performance whether in academics or co-curricular activities, and educate students to become knowledgeable and skillful, with the ability to transfer the knowledge and skills learnt to solving real life problems. Teachers have many roles to play; as instructional experts, managers and counsellors (Moore, 2007). They have to be empathetic and sensitive to students' psychological, emotional, social and academic well-being. As specified in The National Education Philosophy of Malaysia (MOE, 2016), teachers are responsible for producing individuals who are intellectually, spiritually, emotionally and physically balanced and harmonious, based on a firm belief in and devotion to God. In addition, teachers are expected to produce Malaysian citizens who are knowledgeable and competent, who possess high moral standards, and who are responsible and capable of achieving high level of personal goals. The National Education Philosophy of Malaysia also attempts to produce citizens who are able to contribute to the harmony and betterment of the family, society, and the country (MOE, 2016).

Teacher education programs must look into ways to produce teachers who are well-qualified, competent and have the ability to work professionally to solve issues involving the multi-faceted dimensions of education. One central issue that should not be overlooked is teaching critical problem-solving skills within various subjects and disciplines. In this study, problem-solving is related to ESL writing instruction. Writing skills is chosen because it is one of the most important skills taught in the Malaysian School English Curriculum. However, it is a difficult skill to learn and master (Kwan \& Yunus, 2014; Nunan, 1999; White \& Arndt; 1991). Nunan (1999) states that producing coherent written discourse is challenging for many native speakers, and "for second language learners, the challenges are enormous" (p. 271). A study in Malaysia's TESL teacher education faculty found that Malaysian ESL pre-service teachers have not entirely mastered their writing skills what more teaching this skill to students. Writing is a skill that is difficult to teach and master, and teachers often face problems in teaching students on how to become skillful writers (Nguyen and Hudson, 2010). Many pre-service teachers are worried about teaching, and their students 'learning (Goh \& Matthews, 2011; Greiberg \& Driscoll, 2005).

In this study, problem-solving in the ESL writing instruction relates to pedagogical and content problems. Research shows that "variations in 'opportunities to learn' in teacher preparation are related to differences in student achievement: teachers from countries that are top performers in PISA and TIMSS tend to have more opportunities to learn content, pedagogical content and general pedagogy" (Guerriero, 2013, p. 3). It is found that amongst the features of expert teachers are extensive pedagogical content knowledge, and better problem-solving strategies (Guerriero, 2013). Making PCK explicit to participants in interventions could help in the development of their PCK (Evens, Elen \& Depaepe, 2015). The training, study and practice of PCK should be done in domain specific contexts to enhance PCK of the subject and skills the teachers are teaching $(\mathrm{Xu}, 2015)$.

In this study, pre-service teachers observe an authentic ESL writing lesson and engage in problem-solution analysis relating to pedagogy and content of ESL writing. These aspects are focused 
INTERNATIONAL JOURNAL OF ACADEMIC RESEARCH IN BUSINESS AND SOCIAL SCIENCES

Vol. 9, No. 13, Special Issue: Revolutionizing Education: Challenges, Innovation, Collaboration., 2019, E-ISSN: 2222-6990 @ 2019 HRMARS

on because of the importance of pedagogical content knowledge (PCK) amongst teachers (Shulman, 1986; 1987). PCK makes a difference for instructional quality and student learning (Evens et al., 2015). PCK in teachers powerfully impacts students' progress and instructional quality (Baumert, Kunter, Blum, et al, 2010). Teachers' PCK also correlated with students' motivation and enjoyment to learn (Kunter et al, 2013). These show that attention should be given in the training and development of teachers' and future teachers' PCK to improve the quality of education (Evens et al., 2015).

\section{Statement of the Problem}

It is found that higher education has not prepared pre-service teachers adequately to bridge theory and practice and apply pedagogical content knowledge to solve real-world problems (Choi \& Yong, 2011; Mandl, Gruber \& Renkle, 1996). Pre-service teachers lack content knowledge and do not know how to use suitable teaching methods (Darling-Hammond, 2006). The actual situation shows that many find it hard to teach effectively often due to lack of experience or even not being entirely prepared for the job (Nahal, 2010).

In addition, it was found that Malaysian pre-service teachers did not apply theory and practice during practicum teaching, and struggled to apply pedagogical-content knowledge, whilst coping with workload not related to teaching, and practicum supervision (Ong, Ros, Azlian, Sharnti \& Ho, 2004). They have problems teaching mixed-ability classes (Kabilan, 2013; Kabilan \& Raja Ida, 2008). Preservice teachers also expressed concern about how and what to teach, choosing the appropriate and correct methodology, and using current and creative strategies of teaching (Goh \& Matthews, 2011). Norshiha and Norsiah's (2011) study found teacher education programs tend to be isolated from the issues that are prevalent in the classroom such as teaching the socially disadvantaged, new immigrants, and students with mixed abilities. These shows that there are pertinent issues that need to be addressed in the training of pre-service teachers.

Malaysian novice teachers, in their first year of teaching, having transitioned from teacher education to the teaching profession, are not adequately prepared for the challenges of teaching (Senom, Zakaria \& Shah, 2013). A nationwide study conducted by the Ministry of Education and The Ministry of Higher Education (2006) on Malaysian ESL novice teachers' readiness for their teaching profession, found that one of the problems faced is the difficulty in applying theory to practice, among other problems like curriculum specification, resources, teaching preparation, classroom teaching and management. An in-depth investigation found that students' low English proficiency is a frequent problem faced during their first years of teaching (MOHE \& MOE, 2006).

Prospective teachers might face a complex situation and requires them to address complicated issues involving a range of variables and parameters (Nahal, 2010). In reality, teacher education covers a broad range of topics, and pre-service teachers have to be able to apply all the course contents, theories, principles and approaches as students and future teachers (Shulman, 1987). Classroom problem solving often requires making pedagogical and content decisions (Guerriero, 2013; Stuart and Thurlow, 2000). Sharing of perspectives, observation of real classroom teaching and openness to reflection and decision making can help pre-service teachers to re-evaluate and change their beliefs about teaching and become agents of change in their schools (Stuart \& Thurlow, 2000).

Hence, teacher education programs should prepare pre-service teachers to be effective problem-solvers to cater to the current demands and needs of teaching. Pre-service teachers need effective and relevant training in problem-solving and ample training in application of theory, content 
INTERNATIONAL JOURNAL OF ACADEMIC RESEARCH IN BUSINESS AND SOCIAL SCIENCES

Vol. 9, No. 13, Special Issue: Revolutionizing Education: Challenges, Innovation, Collaboration., 2019, E-ISSN: 2222-6990 @ 2019 HRMARS

and pedagogy to teaching. One of the challenges that teacher education needs to pay attention to is how to bridge the gap between training and the actual demands of the teaching profession (Lee, 2004). Many teacher education programs are moving towards reducing the theory-practice gap. Theory that relates to practice will help novice teachers develop intuitive skills in dealing with classroom-related issues (Nahal, 2010).

\section{Literature Review}

While many studies highlight the problems novice teachers face, many do not investigate how the teachers overcome challenges and solve the problems (Senom, Zakaria \& Shah, 2013). Several studies have suggested that teacher knowledge is crucial, and it is important for student teachers to assimilate academic knowledge with knowledge derived from experiential and practical experiences in the classroom (Guerriero, 2013). In teacher education, pre-service teachers need to be trained to foresee future professional problems and how they can apply theoretical, pedagogical and practical strategies to solve the problems. In teacher education training, pre-service teachers need to be given adequate examples. It is important to provide examples especially when teaching conceptual and complex materials (He, Yuan and Yang, 2013). They should be exposed to sufficient examples and case-based approach has been strongly recommended (He, Yuan \& Yang, 2013). This approach has also been found to be effective in bridging the gap between theory and practice (Koc, 2012).

Previous studies on case-based learning have used written real dilemma cases. Koc's (2012) study found written cases to be effective for connecting theory-practice divide, apply theories and content knowledge, and developing effective problem-solving strategies amongst early childhood pre-service teachers. Koc (2012) further suggested the use of video, multimedia and online cases in future research studies. This provides the benefit of accessibility of the participants and any interested party hoping to use cases as a pedagogical tool in teaching and learning.

In addition, video cases presented online can be used in teacher education to develop problem solving abilities. Wong and Hartley (2003) claim that video technologies serve as tools for pre-service teachers to view ill-structured problem scenarios explicitly and repeatedly to identify problems faced in the classroom with the potential of generating effective solutions to the problems identified. Kale and Whitehouse's (2012) study uses Social Studies video case taken from an online problem-based learning video case library. The participants are from various education majors like English, World Languages, Mathematics, general Science, Special Education, and early Childhood. However, the use of video cases in developing problem-solving abilities needs to be further explored as there is lack of empirical support to measure its effectiveness (Kale \& Whitehouse, 2012).

Kocyigit and Zembat (2013) promote the use of authentic tasks that present real-life conditions into pre-service teacher education to helps pre-service teachers to encounter possible future problems and make recommendations. They made use of computer-based presentations and video recording technology of real-life classroom teaching to analyse problems and discuss solutions. While Kocyigit and Zembat (2013) used participants from the Special Education Methods course offered in Pre-school education undergraduate program, they suggested that future investigations should be conducted in other courses.

Case-based learning is gaining popularity for its epistemological foundation that fosters learners' higher cognitive processes, meaningful learning experiences, and effective problem-solving capabilities (Choi \& Lee, 2009; Koc, 2012; Kocyigit \& Zembat, 2013). The use of cases in teacher 
education has been found in courses such as Classroom Management in Education Psychology, Early Childhood Education Programs, and Special Education Methods in Pre-school Education (Choi \& Lee, 2009; Koc, 2012; Kocyigit \& Zembat, 2013). However, there has not been any study done on using case-based learning in a writing methodology course in a TESL teacher education program.

The solution that this study proposes is the development of an Online Case-Based ProblemSolving (OCBPS) Module to address the issues of enhancing problem solving skills, bridging theory and practice, application of pedagogical and content knowledge, and for ESL pre-service teachers to be adequately prepared for their teaching job. This study addresses the gap by providing the opportunity for ESL pre-service teachers to be trained for problem-solving through the OCBPS module. It aims to fill the gap on using online cases in a writing methodology course to help enhance pre-service teachers' problem-solving abilities, develop the application of pedagogical content knowledge, develop the ability to bridge theory and practice and prepare them for writing instruction.

\section{Methodology}

Before the OCBPS module is implemented, 19 TESL pre-service teachers from the Faculty of Education of a public university write a pre-reflection essay on the problems ESL teachers encounter in ESL writing instruction in rural secondary schools. In the implementation of the module, the preservice teachers observe an authentic ESL writing lesson in a rural context and engage in problemsolution analysis relating to pedagogy and content of ESL writing. They write a post reflection essay after the module is implemented. Two raters rated the pre- and post-reflective essays and a PairedSamples T-Test for Inter-Rater Reliability was done From the analysis, it was found that there is no significant difference between the scores given by Rater 1 and Rater 2 with a value of $\alpha=0.062$, hence there is inter-rater reliability.

A Single-Group Pre-test-Post-test Design is adopted in which scores of pre-reflection essays written by the pre-service teachers before the implementation of the module, and the scores of post reflective essays written at the end of the module implementation are compared. The scores of preand post-reflections are compared to determine if there are significant differences in the scores. If the scores have significant difference, it can be concluded that the module is able to improve the preservice teachers' reflective abilities in the following aspects:

1. Pedagogical Content Knowledge

2. Problem-Solving Skills

3. Bridge Theory and Practice

\section{Findings}

Pedagogical Content Knowledge (PCK). The two raters evaluated the pre-service teachers' pre- and post-reflective essays. The scores given for the reflective essays written before and after the module implementation can be compared to determine if the pre-service teachers' pedagogical content knowledge improved from their experience participating in the Online Case-Based Problem-Solving Module. The results are reported below: 
INTERNATIONAL JOURNAL OF ACADEMIC RESEARCH IN BUSINESS AND SOCIAL SCIENCES

Vol. 9, No. 13, Special Issue: Revolutionizing Education: Challenges, Innovation, Collaboration., 2019, E-ISSN: 2222-6990 @ 2019 HRMARS

\section{Normality Test}

Table 1

Kolmogorov-Smirnov and Shapiro-Wilk Test of Normality for PCK

\begin{tabular}{ccccccc}
\hline \multicolumn{6}{c}{ Tests of Normality } \\
\hline \multicolumn{4}{c}{ Kolmogorov-Smirnov } & \multicolumn{3}{c}{ Shapiro-Wilk } \\
\hline Statistic & df & Sig. & Statistic & df & Sig. \\
\hline Diff & .200 & 19 & .044 & .927 & 19 &. $\mathbf{1 5 3}$ \\
\hline \multicolumn{4}{c}{ Normality Test } & \multicolumn{4}{c}{ Shapiro-Wilk } \\
\hline \multicolumn{3}{c}{ Sig. Value } & \multicolumn{4}{c}{$\mathbf{0 . 1 5 3}$} \\
\hline
\end{tabular}

Table 1 above shows the result of testing normality of data using Shapiro-Wilk value. A nonsignificant result (Sig. value of more than 0.05 ) indicates normality. Based on the table above, the sig. value for Shapiro-Wilk is 0.153 and the value is greater than $\alpha=0.05$. Thus, it shows that the data is normally distributed. Since the data is normal, to test for the significance in mean differences for pedagogical content knowledge, the most suitable statistical analysis is paired t-test.

\section{Paired-Sample T-Test for PCK}

Table 2

Paired-Samples T-Test for PCK

Paired Samples Test

\begin{tabular}{|c|c|c|c|c|c|c|c|c|c|}
\hline \multicolumn{10}{|c|}{ Paired Differences } \\
\hline & & \multirow[t]{2}{*}{ Mean } & \multirow[t]{2}{*}{ Std. Dev. } & \multirow{2}{*}{$\begin{array}{l}\text { Std. Error } \\
\text { Mean }\end{array}$} & \multicolumn{2}{|c|}{$\begin{array}{l}\text { 95\% Confidence Interval } \\
\text { of the Difference }\end{array}$} & \multirow[t]{2}{*}{$\mathrm{t}$} & \multirow[t]{2}{*}{$d f$} & \multirow[t]{2}{*}{$\begin{array}{l}\text { Sig. (2- } \\
\text { tailed) }\end{array}$} \\
\hline & & & & & Lower & Upper & & & \\
\hline $\begin{array}{c}\text { Pair } \\
1\end{array}$ & $\begin{array}{l}\text { Pre - } \\
\text { Post }\end{array}$ & -2.89474 & 3.67264 & .84256 & -4.6649 & -1.1246 & -3.436 & 18 & .003 \\
\hline
\end{tabular}

\begin{tabular}{cc}
\hline Test & p-value \\
\hline Paired-Samples T Test & $\mathbf{0 . 0 0 3}$ \\
\hline
\end{tabular}

Based on the table above, the significant value is 0.003 . A significant value is set at $\alpha=0.05$. If the value is less than 0.05 , we can conclude that there is a significant difference between the two scores (pre and post scores). From the analysis, it was found that the significant value $=0.003$ which is less than $\alpha=0.05$, thus we can conclude that there is a significant difference in the scores for pre and post reflections showing improved pedagogical content knowledge.

Problem-Solving (PS). The two raters evaluated the pre-service teachers' pre- and post-reflective essays for problem-solving skills. The scores given for the reflective essays written before and after the module implementation can be compared to determine if the pre-service teachers' problem- 
INTERNATIONAL JOURNAL OF ACADEMIC RESEARCH IN BUSINESS AND SOCIAL SCIENCES

Vol. 9, No. 13, Special Issue: Revolutionizing Education: Challenges, Innovation, Collaboration., 2019, E-ISSN: 2222-6990 @ 2019 HRMARS

solving skills improved from their experience participating in the Online Case-Based Problem-Solving Module. The results are reported below:

\section{Normality Test}

Table 3

Kolmogorov-Smirnov and Shapiro-Wilk Test of Normality for PS

\begin{tabular}{|c|c|c|c|c|c|c|}
\hline \multicolumn{7}{|c|}{ Tests of Normality } \\
\hline & \multicolumn{3}{|c|}{ Kolmogorov-Smirnov } & \multicolumn{3}{|c|}{ Shapiro-Wilk } \\
\hline & Statistic & $\mathrm{df}$ & Sig. & Statistic & $\mathrm{df}$ & Sig. \\
\hline \multirow[t]{3}{*}{ Diff } & .119 & 19 & .200 & .965 & 19 & .672 \\
\hline & \multicolumn{2}{|c|}{ Normality Test } & & \multicolumn{2}{|c|}{ Shapiro-Wilk } & \\
\hline & \multicolumn{2}{|c|}{ Sig. Value } & & \multicolumn{2}{|c|}{0.672} & \\
\hline
\end{tabular}

Table 3 above shows the result of testing normality of data using Shapiro-Wilk value. A nonsignificant result (Sig. value of more than 0.05 ) indicates normality. Based on the table above, the sig. value for Shapiro-Wilk is 0.672 and the value is greater than $\alpha=0.05$. Thus, it shows that the data is normally distributed. Since the data is normal, to test for the significant in mean differences for problem-solving skills, the most suitable statistical analysis is paired t-test.

\section{Paired-Sample T-Test for PS}

Table 4

Paired-Samples T-Test for PS

Paired Samples Test

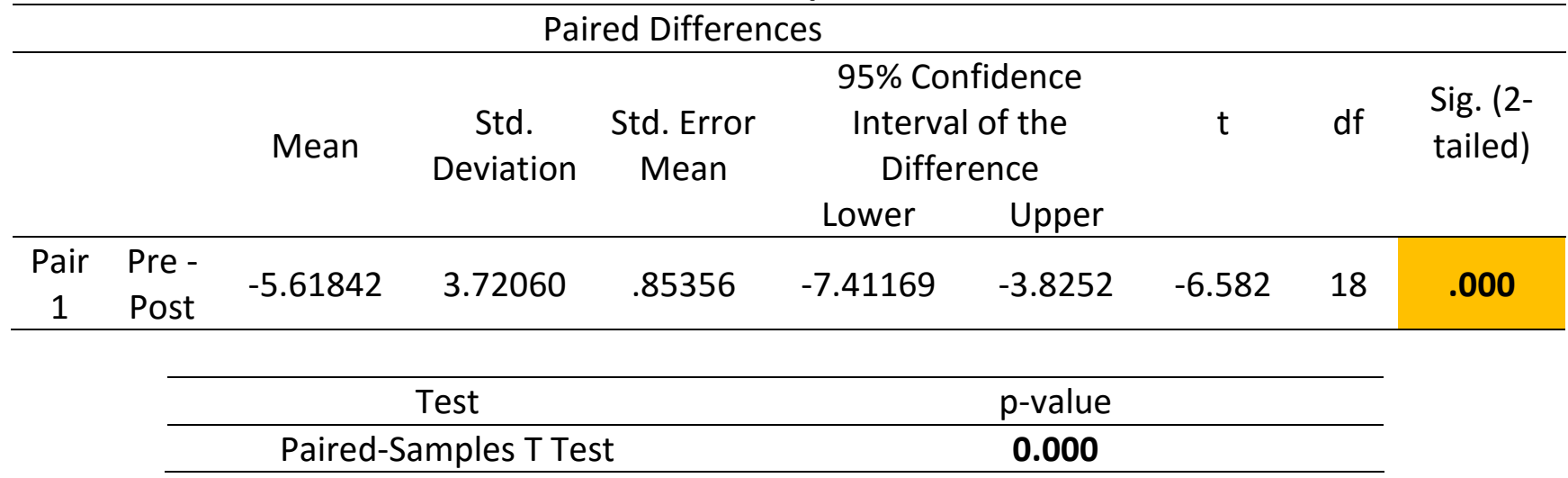

Based on the table above, the significant value is 0.000 . A significant value is set at $\alpha=0.05$. If the value is less than 0.05 , we can conclude that there is a significant difference between the two scores (pre and post scores). From the analysis, it was found that the significant value $=0.000$ is less than $\alpha=0.05$, thus we can conclude that there is a significant difference in the scores for pre and post reflections indicating improved problem-solving skills. 
INTERNATIONAL JOURNAL OF ACADEMIC RESEARCH IN BUSINESS AND SOCIAL SCIENCES

Vol. 9, No. 13, Special Issue: Revolutionizing Education: Challenges, Innovation, Collaboration., 2019, E-ISSN: 2222-6990 @ 2019 HRMARS

Application of Theory-Practice (TP). The two raters evaluated the pre-service teachers' pre- and post-reflective essays for application of theory and practice. The scores given for the reflective essays written before and after the module implementation can be compared to determine if the pre-service teachers' application of theory and practice improved from their experience participating in the Online Case-Based Problem-Solving Module. The results are reported below:

\section{Normality Test}

Table 5

Kolmogorov-Smirnov and Shapiro-Wilk Test of Normality for TP

\begin{tabular}{ccccccc}
\hline \multicolumn{8}{c}{ Tests of Normality } \\
\hline \multicolumn{4}{c}{ Kolmogorov-Smirnov } & \multicolumn{3}{c}{ Shapiro-Wilk } \\
\hline Diff & Statistic & df & Sig. & Statistic & df & Sig. \\
\hline & .110 & 19 & $.200^{*}$ & .975 & 19 & .862 \\
\hline \multicolumn{4}{c}{ Normality Test } & \multicolumn{5}{c}{ Shapiro-Wilk } \\
\hline \multicolumn{3}{c}{ Sig. Value } & \multicolumn{4}{c}{$\mathbf{0 . 8 6 2}$} \\
\hline
\end{tabular}

Table above shows the result of testing normality of data using Shapiro-Wilk value. A nonsignificant result (Sig. value of more than 0.05 ) indicates normality. Based on the table above, the sig. value for Shapiro-Wilk is 0.862 and the value is greater than $\alpha=0.05$. Thus, it shows that the data is normally distributed. Since the data is normal, to test for the significant in mean differences for application of theory and practice, the most suitable statistical analysis is paired t-test.

\section{Paired-Sample T-Test for TP}

Table 6

Paired-Samples T-Test for TP

Paired Samples Test

\begin{tabular}{|c|c|c|c|c|c|c|c|c|c|}
\hline \multicolumn{10}{|c|}{ Paired Differences } \\
\hline & & \multirow[t]{2}{*}{ Mean } & \multirow[t]{2}{*}{$\begin{array}{c}\text { Std. } \\
\text { Deviation }\end{array}$} & \multirow[t]{2}{*}{$\begin{array}{l}\text { Std. } \\
\text { Error } \\
\text { Mean }\end{array}$} & \multicolumn{2}{|c|}{$\begin{array}{l}\text { 95\% Confidence } \\
\text { Interval of the } \\
\text { Difference }\end{array}$} & \multirow[t]{2}{*}{$\mathrm{t}$} & \multirow[t]{2}{*}{$\mathrm{df}$} & \multirow[t]{2}{*}{$\begin{array}{l}\text { Sig. (2- } \\
\text { tailed) }\end{array}$} \\
\hline & & & & & Lower & Upper & & & \\
\hline \multirow[t]{3}{*}{$\begin{array}{c}\text { Pair } \\
1 \\
\end{array}$} & $\begin{array}{l}\text { Pre - } \\
\text { Post }\end{array}$ & -4.35526 & 4.04258 & .92743 & -6.30373 & -2.40680 & -4.696 & 18 & .000 \\
\hline & \multicolumn{4}{|c|}{ Test } & \multicolumn{4}{|c|}{$p$-value } & \\
\hline & \multicolumn{4}{|c|}{ Paired-Samples T Test } & \multicolumn{4}{|c|}{0.000} & \\
\hline
\end{tabular}

Based on the table above, the significant value is 0.000 . A significant value is set at $\alpha=0.05$. If the value is less than 0.05 , we can conclude that there is a significant difference between the two 
INTERNATIONAL JOURNAL OF ACADEMIC RESEARCH IN BUSINESS AND SOCIAL SCIENCES

Vol. 9, No. 13, Special Issue: Revolutionizing Education: Challenges, Innovation, Collaboration., 2019, E-ISSN: 2222-6990 @ 2019 HRMARS

scores (pre and post scores). From the analysis, it was found that the significant value $=0.000$ is less than $\alpha=0.05$, thus we can conclude that there is a significant difference in the scores for pre and post reflections indicating improved application of theory and practice in the reflection.

Overall Scores. The two raters evaluated the pre-service teachers' pre- and post-reflective essays and obtained the overall scores. The scores given for the reflective essays written before and after the module implementation can be compared to determine if the pre-service teachers' scores improved from their experience participating in the Online Case-Based Problem-Solving Module. The results are reported below:

\section{Normality Test}

Table 7

Kolmogorov-Smirnov and Shapiro-Wilk Test of Normality for Overall Scores

\begin{tabular}{ccccccc}
\hline \multicolumn{8}{c}{ Tests of Normality } \\
\hline \multicolumn{4}{c}{ Kolmogorov-Smirnov } & \multicolumn{3}{c}{ Shapiro-Wilk } \\
\hline Statistic & df & Sig. & Statistic & df & Sig. \\
\hline & .449 & 19 & .000 & .343 & 19 & .000 \\
\hline \multicolumn{3}{c}{ Normality Test } & \multicolumn{5}{c}{ Shapiro-Wilk } \\
\hline \multicolumn{4}{c}{ Sig. Value } & $\mathbf{0 . 0 0 0}$ \\
\hline
\end{tabular}

Table above shows the result of testing normality of data using Shapiro-Wilk value. A nonsignificant result (Sig. value of more than 0.05 ) indicates normality. Based on the table above, the sig. value for Shapiro-Wilk is 0.000 and the value is less than $\alpha=0.05$. Thus, it shows that the data is not normally distributed. Since the data is not normal, to test for the significant in mean differences, the most suitable statistical analysis is Wilcoxon Signed Rank Test.

\section{Wilcoxon Signed Ranked Test}

Table 8

Wilcoxon Signed Rank Test for Overall Scores

\begin{tabular}{lc}
\hline \multicolumn{2}{c}{ Test Statistics } \\
\hline \multicolumn{2}{c}{ Post - Pre } \\
\hline$Z$ & -3.461 \\
\hline $\begin{array}{l}\text { Asymp. Sig. (2- } \\
\text { tailed) }\end{array}$ & .001 \\
\hline
\end{tabular}

\begin{tabular}{cc}
\hline Test & p-value \\
\hline Wilcoxon Signed Rank Test & $\mathbf{0 . 0 0 1}$ \\
\hline
\end{tabular}

Based on the table above, the significant value is 0.001 . A significant value is set at $\alpha=0.05$. If the value is equal to or less than 0.05 , we can conclude that the difference between two scores (pre and post-test) is statistically significant. From the analysis, it was found that the significant value $=$ 
INTERNATIONAL JOURNAL OF ACADEMIC RESEARCH IN BUSINESS AND SOCIAL SCIENCES

Vol. 9, No. 13, Special Issue: Revolutionizing Education: Challenges, Innovation, Collaboration., 2019, E-ISSN: 2222-6990 @ 2019 HRMARS

0.000 is less than $\alpha=0.05$, thus we can conclude that the two sets of scores are significantly different. The overall scores improved after the Online Case-Based Problem-Solving Module was implemented.

Summary of Pre-and Post-Reflective Essay Scores for All Components. The scores of pre- and post-reflections are compared to determine if there are significant differences in the scores and whether the OCBPS module is able to improve the pre-service teachers' abilities in Pedagogical Content Knowledge; Problem-Solving Skills; Bridge Theory and Practice; and Overall Score. The following are the summary of findings for all the components evaluated in the pre-and post-reflective essays.

Table 10

Summary of the Difference in the Mean Scores between Pre and Post Reflective Essays for All Components

\begin{tabular}{ccc}
\hline Components & Test & p-value \\
\hline $\begin{array}{c}\text { Pedagogical Content } \\
\text { Knowledge (PCK) }\end{array}$ & Paired-Samples T-Tests & 0.003 \\
Problem-Solving (PS) & Paired-Samples T-Tests & 0.000 \\
Theory-Practice (TP) & Paired-Samples T-Tests & 0.000 \\
Overall & Wilcoxon Signed Rank Test & 0.001 \\
\hline
\end{tabular}

The analysis was done using the Paired-Samples t-test for normal data (PCK, PS, and TP), and Wilcoxon Signed Rank Test for the overall data that is not normally distributed. The significant value is used to determine if there are any significant differences in the scored obtained for pre and postreflective essays. The level of significance was set at $\alpha=0.05$. The output produced shows that the $p$ value obtained for each of the three components; PCK $=0.003$, PS and TP $=0.000$. The $p$-value obtained for each of the component is less than $\alpha=0.05$. It is therefore proven that there are significant differences between the mean scores produced for pre and post-test. The significant differences are apparent in terms of PCK, PS and TP. In addition, the overall scores between pre and post reflective essays show statistically significant difference ( $p$-value $0.001<\alpha=0.05$ ). From the results, it can be concluded that there are significant improvements in the scores obtained by the pre-service teachers in their post reflection essays at the end of the module implementation. This shows that the module is effective in improving the pre-service teachers' abilities to reflect on pedagogical content knowledge, problem-solving, application of theory and practice and the overall abilities in these aspects. 
INTERNATIONAL JOURNAL OF ACADEMIC RESEARCH IN BUSINESS AND SOCIAL SCIENCES

Vol. 9, No. 13, Special Issue: Revolutionizing Education: Challenges, Innovation, Collaboration., 2019, E-ISSN: 2222-6990 @ 2019 HRMARS

\section{Discussion}

The OCBPS module develops pedagogical content knowledge. The module emphasizes on the importance of pedagogical content knowledge and how these two are important for a holistic learning experience. The pre-service teachers said that they were able to apply PCK in the problemsolution task and they will apply PCK in their teaching. From the t-test analysis for PCK, it was found that there is a significant difference in the scores for pre and post reflections showing improved pedagogical content knowledge. The pre-service teachers agree that teachers should be equipped with pedagogical content knowledge for effective instruction. The case-based problem-solving module taught them that pedagogical and content knowledge in combination is important for teachers to apply in their instruction. This is parallel to results from several studies that found casebased learning develops engagement in multiple analysis of problems and justification of solutions (Choi \& Lee, 2013; Pierce, 2002; Merseth, 1999; Harrington, 1995); reasoning clearly and logically (Pierce, 2002).

It was found that the strength of the module is it develops critical problem-solving skills. From the t-test analysis, it was found that there is a significant difference in the scores for pre and post reflections indicating improved problem-solving skills. The pre-service teachers' reflections also revealed that the OCBPS module develops problem-solving skills. According to Merseth (1996), using cases in teacher education is beneficial because of first, "the ability of cases to help develop problem solving and decision-making skills"; second, "the ability of cases to increase awareness of multiple perspectives and other educational settings"; third, "the ability of cases to enhance beliefs about personal authority and efficacy"; and fourth, "the ability of cases to form habits of reflection" (p. 731). Research has shown that online video cases can support problem solving skills (Choi, 2007; Choi \& Johnson, 2007; Henson, Kennett \& Kennedy, 2003; Pierce, 2002).

The module is also able to bridge theory and practice. From the t-test analysis, it was found that there is a significant difference in the scores for pre and post reflections indicating improved application of theory and practice in the reflection. The OCBPS module has helped the pre-service teachers to have a frame of reference of the theories and approaches they have learnt. Being prepared to use the theories and approaches can guide the pre-service teachers during practicum and as future teacher. This finding is similar to the finding by Koc (2012) that the use of case-based learning in the early childhood courses was effective in promoting theory-practice connections. Other researchers found that case-based learning develops application of theories to the learning process (Choi \& Lee, 2013; Koc, 2012; Henson et al., 2003; Merseth, 1999). The use of case-based learning with videos has a promising potential of establishing the essential connection between theory and practice (Blomberg et al., 2013).Teacher knowledge is context-specific, non-stagnant, and evolving (Clark \& Lampert, 1986), thus it should be learned in context rather than in complex abstraction (Ozkan, 2001). One way of learning in-context is through case observations rather than from textbooks. Constructivism supports pre-service teachers' acquisition of teacher knowledge because of its principles of combining theory and praxis (Ozkan, 2001). The finding is supported by the principles of constructivism.

\section{Conclusion}

Online cases have been used to present real-life problems (Choi \& Lee, 2009). In the current study, the video case is recorded in a real classroom in a public secondary school for secondary 
education Teaching English as Second Language (TESL) pre-service teachers. The researcher captures a case in a writing classroom for the ESL writing methodology course participants with the hope that they can apply the theories and approaches learnt in the course for their PCK problem-solving processes. The video case presented is generated from a localized professional setting and directly related to the participants' area of specialization for it to be domain specific. This current study is significant in that it develops situations that prospective teachers will likely encounter providing online resources that are authentic to the Malaysian context for teacher education programs especially the TESL program to use for instructional purposes.

The Online Case-Based Problem-Solving Module for ESL Writing Instruction has never been developed before. It is developed to address issues pertaining to teacher-education that have received prominent attention. It also addresses the lack of research on the case-based learning pedagogy in an ESL writing methodology course. The development of this module is to address the lack of problem-solving skills in Malaysian students and the need to enhance this skill as proposed in the Malaysian Education Blueprint (2015-2025). At a macro level, the OCBPS module is a significant contribution to stakeholders. At a micro level, it is significant to teacher educators, pre-service teachers, policy makers, teachers, researchers, and those interested in developing instructional online case-based modules for improving pedagogical and content problem-solving skills and in the process link theory and practice. This study shows the potential that case-based learning has in developing problem-solving skills, pedagogical content knowledge, bridge theory and practice, preparation for teaching, and in enhancing other skills that are essential in teacher education in producing teachers with $21^{\text {st }}$ century skills. This study provides the implications that more studies of this nature is needed to provide more platforms for the training of vital skills, and knowledge growth in various domains of teacher education.

\section{References}

Arellano, E. L. (2002). Developing a Critically Reflective Practice Through Case-Based Pedagogy. JOURNAL OF SCIENCE AND MATHEMATICS EDUCATION IN SOUTHEAST ASIA, 25(1), 136-154. Retrieved from http://www.recsam.edu.my/R\&D_Journals/YEAR2002/2002Vol25No1/136-154.pdf

Baumert, J., Kunter, M., Blum, W., Brunner, M., Voss, T., Jordan, A., ... \& Tsai, Y. M. (2010). Teachers' mathematical knowledge, cognitive activation in the classroom, and student progress. American Educational Research Journal, 47(1), 133-180.

Blomberg, G., Renkl, A., Sherin, M. G., Borko, H., \& Seidel, T. (2013). Five research-based heuristics for using video in pre-service teacher education. Journal for educational research online, 5(1), 90.

Choi, H. J. (2007). College Students' Perceptions of Learning and Knowledge Transfer in ProblemBased Video Instruction: A Case Study. Journal of Learning Design, 2(2), 105-115.

Choi, H. J., \& Johnson, S. D. (2005). The effect of context-based video instruction on learning and motivation in online courses. The American Journal of Distance Education, 19(4), 215-227.

Choi, H. J., \& Johnson, S. D. (2007). The effect of problem-based video instruction on learner satisfaction, comprehension and retention in college courses. British Journal of Educational Technology, 38(5), 885-895. 
INTERNATIONAL JOURNAL OF ACADEMIC RESEARCH IN BUSINESS AND SOCIAL SCIENCES

Vol. 9, No. 13, Special Issue: Revolutionizing Education: Challenges, Innovation, Collaboration., 2019, E-ISSN: 2222-6990 @ 2019 HRMARS

Choi, I., \& Lee, K. (2009). Designing and implementing a case-based learning environment for enhancing ill-structured problem solving: Classroom management problems for prospective teachers. Educational Technology Research and Development, 57(1), 99-129.

Clark, C., \& Lampert, M. (1986). The study of teacher thinking: Implications for teacher education. Journal of teacher education, 37(5), 27-31.

Darling-Hammond, L. (2006). Powerful teacher education. San Fransisco: Jossey-Bass.

Evens, M., Elen, J., \& Depaepe, F. (2015). Developing pedagogical content knowledge: Lessons learned from intervention studies. Education Research International, 2015.

Freiberg, H. J. (2005). School climate: Measuring, improving and sustaining healthy learning environments. Routledge.

Goh, P. S., \& Matthews, B. (2011). Listening To the Concerns of Student Teachers In Malaysia During Teaching Practice. Australian Journal of Teacher Education, 36(3). http://dx.doi.org/10.14221/ajte.2011v36n3.2

Guerriero, S. (2013). Teachers' pedagogical knowledge and the teaching profession. OECD. Accessed April, 17, 2018.

Harrington, H. L. (1995). Fostering reasoned decisions: Case-based pedagogy and the professional development of teachers. Teaching and Teacher Education, 11(3), 203-214.

He, W., Yuan, X., \& Yang, L. (2013). Supporting case-based learning in information security with web-based technology. Journal of Information Systems Education, 24(1), 31-40.

Henson, S. W., Kennett, P. A., \& Kennedy, K. N. (2003). Web-based cases in strategic marketing. Journal of Marketing Education, 25(3), 250-259. Retrieved from http://search.proquest.com/docview/204415064 ?accountid $=28930$

Jonassen, D. H. (2002). Engaging and supporting problem solving in online learning. Quarterly Review of Distance Education, 3(1), 1-13.

Kabilan, M. K. (2013). A phenomenological study of an international teaching practicum: Pre-service teachers' experiences of professional development. Teaching and Teacher Education, 36, 198209

Kabilan, M. K., \& Ida, R. I. (2008). Challenges faced and the strategies adopted by a Malaysian English Language teacher during teaching practice. English Language Teaching, 1(1), 87-95

Kale, U., Whitehouse, P. (2012). Structuring video cases to support future teachers' problem solving. Journal of Research on Technology in Education, 44(3), 177-204.

Koc, I. (2012). Preservice science teachers reflect on their practicum experiences. Educational Studies, 38(1), 31-38

Kocyigit, S., \& Zembat, R. (2013). The Effects of Authentic Tasks on Preservice Teachers' Attitudes towards Classes and Problem Solving Skills. Educational Sciences: Theory and Practice, 13(2), 1045-1051.

Kunter, M., Klusmann, U., Baumert, J., Richter, D., Voss, T., \& Hachfeld, A. (2013). Professional competence of teachers: Effects on instructional quality and student development. Journal of Educational Psychology, 105(3), 805.

Kwan, L. S., \& Yunus, M. M. (2014). Cohesive errors in writing among ESL pre-service teachers. English Language Teaching, 7(11), 130.

Le Maistre, C., \& Paré, A. (2010). Whatever it takes: How beginning teachers learn to survive. Teaching and teacher education, 26(3), 559-564. 
INTERNATIONAL JOURNAL OF ACADEMIC RESEARCH IN BUSINESS AND SOCIAL SCIENCES

Vol. 9, No. 13, Special Issue: Revolutionizing Education: Challenges, Innovation, Collaboration., 2019, E-ISSN: 2222-6990 @ 2019 HRMARS

Lee, M. N. N. (2004). Malaysian teacher education into the new century. In Cheng, Y. C.; Chow, K. W., \& Mok, M. C. (eds). Reform of teacher education in Asia-pacific in the new millennium: Trends and challenges (81-91). Kluwer Academic Publishers.

Mandl, H., Gruber, H., \& Renkl, A. (1996). Communities of practice toward expertise: Social foundation of university instruction. In P. B. Bates \& U. M. Staudinger (Eds.), Interactive minds. Life-span perspectives on the social foundation of cognition (pp. 394-412). Cambridge: Cambridge University Press.

Merseth, K. (1996). "Cases and case methods in teacher education”. In J. Sikula (Ed.), Handbook of research on teacher education (pp.722-744). New York: MacMillan Publishing Company.

Merseth, K. (1999). A rationale for case-based pedagogy in teacher education. In Lundeberg, M; Levin, B. \& Harrington, H. (Eds.). Who learns what from cases and how? The research base for teaching and learning with cases. Mahwah, NJ: Lawrence Erlbaum.

Ministry of Education (MOE). (2014). Malaysia Education Blueprint 2013-2025. Retrieved from Ministry of Education Malaysia: Education Performance and Delivery Unit (PADU) website at http://www.padu.edu.my/index.php/en/2013-12-05-05-10-59

Ministry of Education (MOE). (2016). Malaysia Education Blueprint 2015-2025. Retrieved from Ministry of Education Malaysia: Education Performance and Delivery Unit (PADU) website at http://www.padu.edu.my/index.php/en/2016-12-05-05-10-59

Ministry of Education (MOE). (2016). National Education Philosophy. Retrieved from MOE Official website at http://www.moe.gov.my/v/falsafah-pendidikan-kebangsaan

Ministry of Education (MOE). 2014. Newspaper Clippings. Retrieved from MOE official website (Media) at http://www.moe.gov.my/v/keratan-akhbar-view?id=4090\&

Ministry of Higher Education \& Ministry of Education (2006). Professionalism readiness of novice teachers: suggested training module. Penerbitan Fakulti Pendidikan. UKM.

Moore, K. D. (2007). Classroom teaching skills (6 $6^{\text {th }}$ Ed.). Mc Graw Hill. NY.

Moore, K. D. (2014). Effective instructional strategies: From theory to practice. SAGE Publications.

Nahal, P. (2010). Voices from the field: Perspectives of first-year teachers on the disconnect between teacher preparation programs and realities in the classroom. Research in Higher Education Journal, 8, 1-19.

Nguyen, H. T. M., \& Hudson, P. (2010). Pre-service EFL teachers' beliefs about teaching writing and learning to teach writing before their practicum: A case study in Vietnam. Asian EFL Journal, 12(2), 43-67. Retrieved from http://eprints.qut.edu.au/27588/1/27588.pdf

Norshiha Saidin \& Norsiah Sirun. (2011). Preparing qualified teachers our children deserve. Malaysian Education Deans' Council Journal, 7 (Special Edition), 80-96.

Nunan, D. (1999). Second Language Teaching and Learning. Boston: Heinle \& Heinle Publishers.

Ong, S. K., Ros, A. S., Azlian, A. A., Sharnti, K., \& Ho, L. C. (2004). Trainee teachers' perceptions of the school practicum. Paper presented at the conference of the National Seminar on English Language Teaching 2004. Bangi, Malaysia.

Ozkan, B. (2001). The use of video cases in teacher education. The Turkish Online Journal of Educational Technology - TOJET. October 2002 ISSN: 1303-6521 Vol. 1(1) Article 6: 37-40. Retrieved from http://www.tojet.net/articles/v1i1/116.pdf 
Pearce, R. J. (2002). Case-based structured conflict: A means for enhancing classroom learning. Journal of Management Education, 26(6), 732. Retrieved from http://search.proquest.com/docview/195716705 ?accountid $=28930$

Senom, F., Zakaria, A. R., \& Shah, S. S. A. (2013). Novice teachers' challenges and survival: where do Malaysian ESL teachers stand? American Journal of Educational Research, 1(4), 119-125.

Shulman, L. (1996). Just in case: Reflections on learning from experience. In Colbert, J.; Trimble, K.; \& Desberg, P. (Eds.) The case for education: Contemporary approaches for using case methods. Boston. MA: Allyn \& Bacon.

Shulman, L. S. (1986). Those who understand: Knowledge growth in teaching. Educational Researcher, 15(2), 4-14.

Shulman, L. S. (1987). Knowledge and teaching: Foundation for a new reform. Harvard Educational Review, 57(1), 1-22.

Stuart, C., \& Thurlow, D. (2000). Making it their own: Pre-service teachers' experiences, beliefs and classroom practices. Journal of Teacher Education, 51(2). 113-121.

Wang, J., \& Hartley, K. (2003). Video technology as a support for teacher education reform. Journal of Technology and Teacher Education, 11 (1), 105-138.

White, R., \& Arndt, V. (1999). Process Writing. Harlow: Longman.

$\mathrm{Xu}, \mathrm{W}$. (2015). Exploring ESL/EFL teachers' pedagogical content knowledge on reading strategy instruction. English Language Teaching, 8(11), 155.

Yunus, M. M., Hashim, H., Ishak, N. M., \& Mahamod, Z. (2010). Understanding TESL pre-service teachers' teaching experiences and challenges via post-practicum reflection forms. ProcediaSocial and Behavioral Sciences, 9, 722-728. 